\title{
Hand Hygiene Compliance in Some Intensive Care Units of Turkey: Results of Multicentre Asklepeion Study
}

\author{
Türkiye'deki Bazı Yoğun Bakımlarda El Hijyeni Uyum Oranları: Çok Merkezli Asklepeion \\ Çalışmasının Sonuçları
}

\author{
๑ A Ayşe UYAN ÖNAL ${ }^{1}$, ๑ Firdevs AKSOY ${ }^{2}$, ๑ Emel AZAK ${ }^{3}$, ๑ Meliha MERIÇ KOÇ ${ }^{4}, \oplus$ Sevil ALKAN ÇEVIKER ${ }^{5}$, \\ ๑ (๖ Çiğdem ATAMAN HATIPOĞLU ${ }^{6}$, ๑ Ramazan GÖZÜKÜçÜK ${ }^{7}$, ๑ Emine SEHMEN ${ }^{8}$, ๑ Kenan UĞURLU ${ }^{9}$, ๑ Güneş ŞENOL ${ }^{10}$,

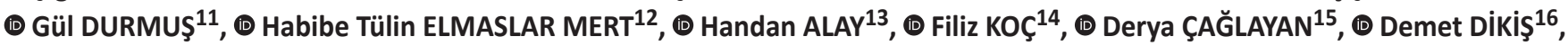

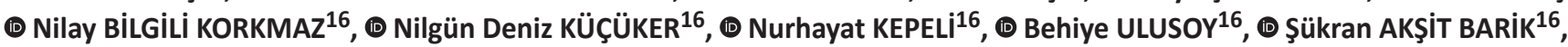

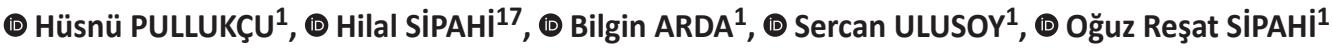 \\ ${ }^{1}$ Ege University Faculty of Medicine, Department of Infectious Diseases and Clinical Microbiology, Izmir, Turkey \\ ${ }^{2}$ Karadeniz Technical University Facult of Medicine, Department of Infectious Diseases and Clinical Microbiology, Trabzon, Turkey \\ ${ }^{3}$ Kocaeli University Faculty of Medicine, Department of Infectious Diseases and Clinical Microbiology, Kocaeli, Turkey \\ ${ }^{4}$ Bezmialem Vakıf University Faculty of Medicine, Department of Infectious Diseases and Clinical Microbiology, Istanbul, Turkey \\ ${ }^{5}$ Balıkesir State Hospital, Clinic of Infectious Diseases and Clinical Microbiology, Balıkesir, Turkey \\ ${ }^{6}$ Ankara Training and Research Hospital, Department of Infectious Diseases and Clinical Microbiology, Ankara, Turkey \\ 7Special Hisar Intercontinental Hospital, Clinic of Infectious Diseases and Clinical Microbiology, İstanbul, Turkey \\ 8 Samsun Gazi State Hospital, Clinic of Infectious Diseases and Clinical Microbiology, Samsun, Turkey \\ 925 Aralık State Hospital, Clinic of Infectious Diseases and Clinical Microbiology, Gaziantep, Turkey \\ ${ }^{10}$ Dr. Suat Seren Chest Diseases and Chest Surgery Training Hospital, Clinic of Infectious Diseases and Clinical Microbiology, izmir, Turkey \\ ${ }^{11 B u r s a}$ Yüksek ihtisas Training and Research Hospital, Clinic of Infectious Diseases and Clinical Microbiology, Bursa, Turkey \\ ${ }^{12}$ Ardahan State Hospital, Clinic of Infectious Diseases and Clinical Microbiology, Ardahan, Turkey \\ ${ }_{13}$ Nenehatun Obstetrics and Gynecology Hospital, Clinic of Infectious Diseases and Clinical Microbiology, Erzurum, Turkey \\ ${ }^{14 K e}$ Ķiören Training and Research Hospital, Clinic of Infectious Diseases and Clinical Microbiology, Ankara, Turkey \\ ${ }_{15}$ Torbalı State Hospital, Clinic of Infectious Diseases and Clinical Microbiology, Izmir, Turkey \\ ${ }^{16}$ Ege University Faculty of Medicine, Hospital Infection Control Committee, Izmir, Turkey \\ ${ }^{17}$ Bornova Public Health Center, Izmir, Turkey
}

\section{Abstract}

Introduction: Hand hygiene is one of the most cost-effective infection control measures. In this multicenter study we analyzed the hand hygiene compliance observation results of 15 hospitals in Turkey.

Materials and Methods: This study was performed in the intensive care units of 15 hospitals (eight tertiary-care educational hospitals, six state hospitals, and one private hospital) from 11 cities located in six regions of Turkey. The observations were made by infection control practitioners according to the World Health Organization (WHO) - Five Moments for Hand Hygiene (WHO-5) indications rule for hand hygiene and overall compliance rates were calculated. Observations were unblinded (healthcare professionals knew that they were observed). The study period included 2015 and 2016 calendar years.

Results: There was a statistically significant increase in hand hygiene compliance rates in 2016 versus 2015. The overall number of hand hygiene opportunities and instances of compliance in 2015 and 2016 were 60071/78116 (76.9\%) and 66551/83607 (79.6\%) ( $p=0.0001)$, respectively. Nurses

Cite this article as: Uyan Önal A, Aksoy F, Azak E, Meriç Koç M, Alkan Çeviker S, Ataman Hatipoğlu Ç, Gözüküȩük R, Sehmen E, Uğurlu K, Şenol G, Durmuş G, Elmaslar Mert HT, Alay H, Koç F, Çağlayan D, Dikiş D, Bilgili Korkmaz N, Deniz Küççüker N, Kepeli N, Ulusoy B, Akşit Barik Ş, Pullukçu H, Sipahi H, Arda B, Ulusoy S, Sipahi OR. Hand Hygiene Compliance in Some Intensive Care Units of Turkey: Results of Multicentre Asklepeion Study. Mediterr J Infect Microb Antimicrob. $2018 ; 7: 37$. 


\section{Abstract}

were the most compliant group in both years. The highest compliance was after body fluid exposure (88.2\% in 2015 and 91.4\% in 2016), while the lowest compliance was before patient contact (61.3\% in 2015 and 65\% in 2016).

Conclusion: The presented data suggest that under unblinded observations, hand hygiene compliance seems to be in relatively acceptable rates in Turkey. Centers with compliance rates below the $50^{\text {th }}$ percentile in any of the five moments should increase efforts to enhance compliance for that indication.

Keywords: Infection control and prevention, epidemiology, nosocomial, hospital-acquired infections, healthcare-associated infections

\section{Öz}

Giriş: El hijyeni en maliyet etkin enfeksiyon kontrol önlemlerinden biridir. Bu çok merkezli çalışmada, Türkiye'deki 15 hastanenin el hijyeni uyumu gözlem sonuçları analiz edildi.

Gereç ve Yöntem: Bu çalışma Türkiye'nin altı bölgesindeki, 11 ilinde bulunan 15 hastanede (sekiz üçüncü basamak eğitim, altı devlet, bir özel hastane) gerçekleştirildi. Gözlemler, Dünya Sağlık Örgütü-5 endikasyonları el hijyeni kurallarına göre enfeksiyon kontrol uygulayıcıları tarafından yapıldı ve genel uyum oranları hesaplandı. El hijyeni gözlemleri kör olmayan şekilde yapıldı (unblinded - sağlık personelleri gözlem sırasında gözlemlendiklerini bilmekteydiler). Çalışmada, çalışmaya katılan merkezlerin 2015 ve 2016 takvim yıllarına ait el hijyeni uyum verileri toplandı.

Bulgular: El hijyeni uyumu açısından 2015 ve 2016 yılları arasında istatistiksel olarak anlamlı artış saptandı. El hijyeni endikasyonu gözleminin toplam sayısı ve uyum oranları 2015 ve 2016 için sırasıyla 60071/78116-076,9 ve 66551/83607-0\%79,6 idi ( $p=0.0001)$. Hemşireler her iki yılda da uyum oranı en yüksek grup olarak saptandı. En yüksek uyum oranları vücut sıvısı ile temas sonrası saptanırken (2015'de \%88,2 ve 2016'da \%91,4), en düşük el hijyeni uyum oranları hasta temasından önce saptandı (2015'de \%61,3 ve 2016'da \%65).

Sonuç: Sunulan veriler, kör olmayan gözlemler altında, Türkiye'deki el hijyeni uyumunun göreli olarak kabul edilebilir oranlarda olduğunu göstermektedir. Beş endikasyonun herhangi birinde 50 persantil oranının altında kalan merkezlerin o endikasyondaki uyumu artırmak için çaba göstermesi önemlidir.

Anahtar Kelimeler: Enfeksiyon kontrolü ve korunma, epidemiyoloji, nozokomiyal, hastane-kaynaklı enfeksiyonlar, sağlık bakımı ile ilişkili enfeksiyonlar

\section{Introduction}

In spite of developments in antimicrobial agents, medicine, infection control practices, and intensive care unit (ICU) care, nosocomial and/or healthcare-associated infections (HCAI) are still associated with significant mortality and morbidity in many countries including Turkey ${ }^{[1,2]}$. It is estimated that more than 1.4 million patients worldwide are affected by $\mathrm{HCAl}$ in developed and developing countries ${ }^{[3]}$. In 1846, Semmelweis ${ }^{[4]}$ was one of the pioneers to demonstrate the importance of hand hygiene in medical care. Hand hygiene is currently considered to be one of the most cost-effective infection control measures ${ }^{[5]}$.

In 2009, the World Health Organization (WHO) recommended the use of Five Moments for Hand Hygiene (WHO-5)-before touching a patient (Moment 1), before a clean/aseptic procedure (Moment 2), after body fluid exposure risk (Moment 3), after touching a patient (Moment 4), and after touching a patient's surroundings (Moment 5)-to improve hand hygiene compliance among healthcare workers ${ }^{[3]}$. The increase in hand hygiene compliance rates with WHO-5 have been shown in many studies ${ }^{[6-8]}$. In this multicenter study, we analyzed the hand hygiene compliance observation results of 15 hospitals in Turkey.

\section{Materials and Methods}

The planned study was announced in the e-mail communication group of the Infectious Diseases and Clinical Microbiology Specialty Society of Turkey (Turkey-EKMUD-www.ekmud.org.tr) and all study sites that accepted the invitation were included in the study.

The study was performed in the ICUs of 15 hospitals (eight tertiary-care educational hospitals, six state hospitals, and one private hospital) from 11 cities located in six regions of Turkey. We retrospectively pooled hand hygiene data that were collected prospectively by each center. The observations were made by infection control practitioners according to the WHO5 indications rule for hand hygiene and overall compliance rates were calculated. Observations were unblinded (healthcare professionals knew that they were observed). The study period included the 2015 and 2016 calendar years.

\section{Statistical Analysis}

Statistical analysis was performed by using chi-square test via the Statistical Package for the Social Sciences 24 program. A $p$ value less than 0.05 was considered to be significant and continuity correction was used to determine $p$ value. 


\section{Results}

There was a statistically significant increase in hand hygiene compliance rates in 2016 versus 2015. The overall number of hand hygiene indications and compliance in 2015 and 2016 were 60071/78116 (76.9\%) and 66551/83607 (79.6\%), respectively $(p=0.0001)$. Nurses were the most compliant (80.4$83.3 \%)$ subgroup in both years while physicians were the least compliant (71.8-75.3\%) subgroup. In terms of the 5 moments, the highest compliance was after body fluid exposure (88.2\% in 2015 and $91.4 \%$ in 2016) while the lowest compliance was before patient contact (61.3\% in 2015 and 65\% in 2016). Overall data are summarized in Table 1.
The $25^{\text {th }}, 50^{\text {th }}$, and $75^{\text {th }}$ percentile values of 2016 for overall hand hygiene compliance in the study hospitals were $66.0 \%, 79.2 \%$, and $87.5 \%$, respectively (Table 2 ).

\section{Discussion}

Hand hygiene is one of the simplest and most cost-effective ways to prevent HCAI. One milestone study regarding the importance of hand hygiene on hospital infections was by Pittet et al. ${ }^{[5]}$, who showed that hand hygiene compliance rates increased from $48 \%$ to $66 \%$ after an extended program while there were significant decreases during the same period in the prevalence of nosocomial infections (16.9\% in 1994 to $9.9 \%$ in 1998; $p=0.04$ ) and methicillin resistant Staphylococcus aureus

Table 1. Overall hand hygiene compliance data of study hospitals in 2015 and 2016

\begin{tabular}{|c|c|c|c|c|c|c|c|c|c|c|c|c|c|}
\hline 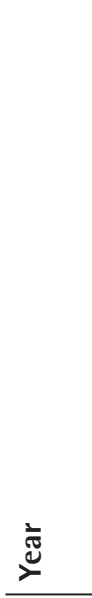 & & 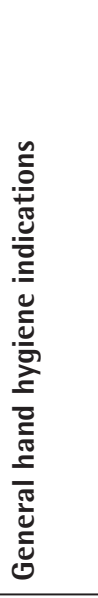 & 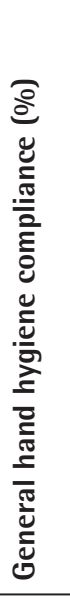 & 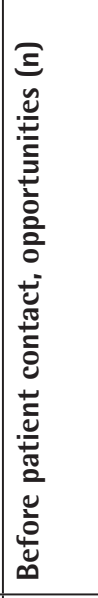 & 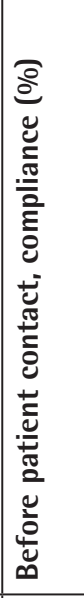 & 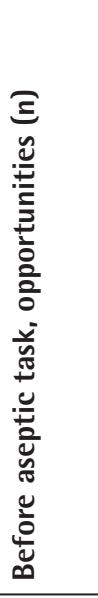 & 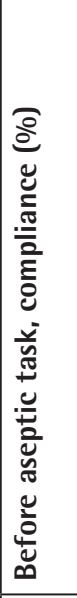 & 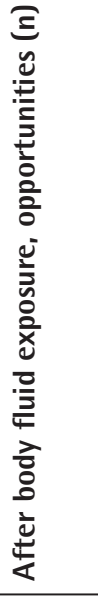 & 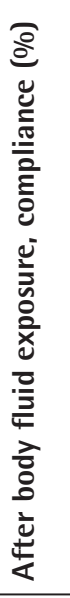 & 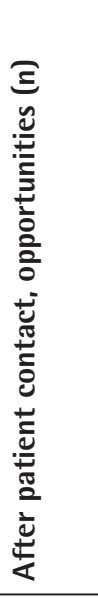 & 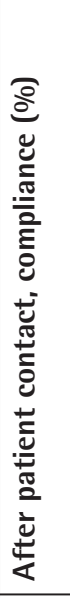 & 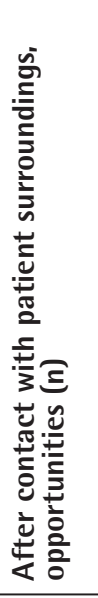 & 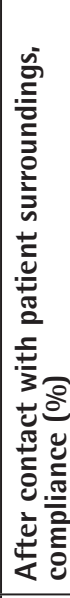 \\
\hline \multirow{4}{*}{2015} & Doctors & 15704 & 71.8 & 3222 & 57.2 & 2855 & 70.1 & 2868 & 84.2 & 3771 & 79.3 & 2966 & 70.3 \\
\hline & Nurses & 47818 & 80.4 & 10719 & 70.1 & 8403 & 73.9 & 8130 & 90.0 & 11626 & 87.1 & 9506 & 79.5 \\
\hline & Other healthcare workers & 13666 & 74.1 & 2999 & 55.4 & 1751 & 82.0 & 2488 & 83.1 & 3078 & 77.0 & 3342 & 76.0 \\
\hline & Overall & 78116 & 76.9 & 16933 & 61.3 & 13075 & 70.9 & 13507 & 88.2 & 18867 & 83.9 & 15773 & 76.0 \\
\hline \multirow{4}{*}{2016} & Doctors & 18338 & 75.3 & 4302 & \begin{tabular}{|l|}
61.1 \\
\end{tabular} & 3291 & 77.2 & 3270 & 89.3 & 3925 & 85.6 & 3405 & 74.3 \\
\hline & Nurses & 50838 & 83.3 & 11771 & 69.7 & 9344 & 75.8 & 9517 & 92.9 & 12007 & 91.1 & 9608 & 84.2 \\
\hline & Other healthcare workers & 14375 & 76.0 & 3794 & 59.7 & 1571 & 77.1 & 2971 & 90.1 & 3360 & 77.6 & 3220 & 75.1 \\
\hline & Overall & 83607 & 79.6 & 20836 & 65.0 & 14900 & \begin{tabular}{|l}
75.9 \\
\end{tabular} & 15764 & 91.4 & 19898 & 86.6 & 16251 & 79.1 \\
\hline
\end{tabular}

Table 2 . The $25^{\text {th }}, 50^{\text {th }}$, and $75^{\text {th }}$ percentile values for 2016 overall hand hygiene compliance in the study hospitals

\begin{tabular}{|c|c|c|c|c|c|c|c|c|c|c|c|c|}
\hline & \multicolumn{3}{|c|}{ Doctors } & \multicolumn{3}{|c|}{ Nurses } & \multicolumn{3}{|c|}{$\begin{array}{c}\text { Other healthcare } \\
\text { workers }\end{array}$} & \multicolumn{3}{|c|}{ Overall } \\
\hline & $25^{\text {th }}$ & $50^{\text {th }}$ & $75^{\text {th }}$ & $25^{\text {th }}$ & $50^{\text {th }}$ & $75^{\text {th }}$ & $25^{\text {th }}$ & $50^{\text {th }}$ & $75^{\text {th }}$ & $25^{\text {th }}$ & $50^{\text {th }}$ & $75^{\text {th }}$ \\
\hline General hand hygiene (\%) & 59.0 & 68.0 & 87.2 & 64.0 & 87.0 & 91.1 & 54.2 & 82.0 & 87.5 & 66.0 & 79.2 & 87.5 \\
\hline Before patient contact (\%) & 39.3 & 58.0 & 74.0 & 56.8 & 73.0 & 83.9 & 40.2 & 53.0 & 60.0 & 47.5 & 68.0 & 78.0 \\
\hline Before aseptic task (\%) & 51.0 & 70.1 & 88.0 & 50.6 & 80.6 & 88.0 & 61.6 & 88.3 & 100 & 49.0 & 75.4 & 83.0 \\
\hline After body fluid exposure (\%) & 73.3 & 91.0 & 100 & 86.0 & 91.2 & 100 & 75.0 & 88.0 & 100 & 84.7 & 87.8 & 99.6 \\
\hline After patient contact $(\%)$ & 60.0 & 80.2 & 92.8 & 78.8 & 87.0 & 94.8 & 59.6 & 87.0 & 93.3 & 73.0 & 87.5 & 92.1 \\
\hline After contact with patient surroundings (\%) & 58.6 & 70.5 & 94.0 & 52.0 & 87.0 & 94.2 & 55.7 & 79.0 & 88.0 & 60.9 & 81.5 & 88.9 \\
\hline
\end{tabular}


transmission rates (2.16 to 0.93 episodes per 10,000 patientdays; $p<0.001)$. Since then, hand hygiene has continued to play a key role in modern infection control practice.

The causes of non-compliance with hand hygiene were investigated in several studies. Lack of soap/paper towels/ hand washing materials, accessible alcoholic hand rubs, and inconveniently located/shortage of sinks were reported to be common reasons ${ }^{[9,10]}$. In a study performed at 41 centers in Turkey on four different days (two days in summer/vacation period and two days in October), there was no soap at 3-11\% of sinks and no paper towels at $10-18 \%$ of sinks on the observation days ${ }^{[10]}$. Heavy workload and lack of staff are also among the causes of poor hand hygiene compliance ${ }^{[11,12]}$. Another multicenter study showed that the healthcare workforce is inadequate, especially in level 3 ICUs in Turkey; approximately 19-30 of 36 level 3 ICUs are working with inadequate nurse work power ( $>2$ patients per nurse ${ }^{[13]}$. In the presented study, we pooled the hand hygiene data of the study centers but did not analyze specific reasons for noncompliance.

There are some arguments regarding the limitations of hand hygiene observations based on WHO-5. Moments 2 and 3 occur in the patient's room in single bed/single room settings and an observer is required to evaluate hand hygiene practices. For more feasible monitoring, at least some of the healthcare institutions in the world are evaluating hand hygiene practices at the entry and exit of the room ${ }^{[14]}$. Sunkesula et al. ${ }^{[14]}$ found that the entry/exit and WHO-5 monitoring methods resulted in similar overall rates of hand hygiene compliance (\%70 vs. \%72). However, the entry/exit method poses a risk since it does not cover contact with body fluids. Moreover, it is not applicable for ICUs without single occupancy rooms ${ }^{[15]}$.

In our study the highest compliance was observed after body fluid exposure (88.2\% in 2015 and $91.4 \%$ in 2016) while the lowest compliance was before patient contact (61.3\% in 2015 and $65 \%$ in 2016). These data suggest that healthcare workers tend to protect themselves. Providing hand hygiene before contact with the patient, prevents possible transmission of resistant microorganisms to the patient $t^{[3]}$.

Hand hygiene observations were made as direct observations in the present study. Direct hand hygiene monitoring by trained personnel is considered to be the gold standard method for hand hygiene compliance monitoring. However, an increase in the rate of hand hygiene compliance can be seen among healthcare workers who are aware of being monitored. Also, observers may not catch $100 \%$ of hand hygiene moments or compliance because they cannot observe 24 hours a day and observations are usually made at room entrances and exits ${ }^{[16]}$. A recent study in Northern Mexico was organized with three phases: in the first phase, the healthcare workers did not know that they were being observed by direct + video observation, while the second phase included feedback on the video observations and compliance rates. At the beginning of the third period, feedback was given again. Hand hygiene compliance rates in phases 1, 2, and 3 were determined as $57 \%, 65 \%$, and $73 \%$ by direct observation versus $21 \%, 34 \%$, and $50 \%$ by video observation ${ }^{[17]}$. In a study conducted by Armellino et al. ${ }^{[18]}$, cameras were installed beside each sink and hand sanitizer dispenser to record hand hygiene practices. Sensors in the doors determined entrances and exits of the personnel. Video supervisors observed hand hygiene at entry and exit. In the corridor-mounted electronic panel, performance feedback was continuously displayed and summary reports were sent to supervisors by e-mail. Hand hygiene rates were less than $10 \%$ in the period with video observation and no feedback and increased to $81.6 \%$ in the period after instant feedback ${ }^{[18]}$. We believe that building such video observation systems in Turkey may provide valuable information about blinded compliance rates.

Hand hygiene compliance rates were $3.9 \%$ and $3.2 \%$ in nurses and doctors, respectively, in a study performed in 2004 at Ege University Hospital ${ }^{[19]}$. In the pediatric ICU of another Turkish tertiary-care educational hospital, hand hygiene compliance rates were $75 \%, 20 \%$, and $5 \%$ in nurses, specialist doctors, and physician assistants in 2012, respectively ${ }^{[20]}$. The Turkish Ministry of Health has been enforcing mandatory hand hygiene observations by Infection Control Committees since 2014. The overall hand hygiene compliance rate in seven ICUs of Ege University was $32 \%$ in 2014 and $55.6 \%$ in $2017^{[9]}$. In a tertiarycare educational hospital in Elazığ Turkey, hand hygiene compliance rate was reported to be $88.3 \%$ ( $92 \%$ for nurses, $84 \%$ for physicians) in 2014-2016 $6^{[2]}$. In the present study, overall hand hygiene rates were $76.9 \%$ and $79.6 \%$ in 2015 and 2016. These studies suggest a marked increase in hand hygiene compliance in the last decade, especially after 2014. However, despite all efforts, hand hygiene compliance could still not be achieved in approximately $20-50 \%$ of healthcare personnel. In addition, none of the centers had data about blinded hand hygiene compliance rates.

Our study has several limitations. This study was performed retrospectively. Observations were made under direct observation. Hence, we do not have data regarding hand hygiene rates in blinded observations. Although the study was performed at 15 centers, it does not represent the whole of Turkey. We did not collect the nosocomial infection rates of the study centers and did not make further analysis, nor did we collect the number of observed healthcare workers. Despite these disadvantages, to our knowledge this is the largest detailed dataset related to this problem and the first study trying to give percentile rates of hand hygiene compliance in Turkey. 


\section{Conclusion}

Although we could not find a standard recommended rate to compare or suggest in the literature, the presented data suggest that in unblinded observations, a hand hygiene compliance rate above the $50^{\text {th }}$ percentile seems to be relatively acceptable in Turkey. In addition, hand hygiene compliance increased further in 2016. We may suggest that the Turkish Ministry of Health, which collects national hand hygiene data, add hand hygiene rates to annual nosocomial infection surveillance reports. Centers with compliance rates below the 50 percentile in any of the five moments should increase efforts to enhance compliance for that indication.

\section{Ethics}

Ethics Committee Approval: Retrospective study.

Informed Consent: Retrospective study.

Peer-review: Externally and internally peer-reviewed.

\section{Authorship Contributions}

Concept: A.U.Ö., O.R.S., Design: A.U.Ö., O.R.S., Data Collection or Processing: All authors, Literature Search: A.U.Ö., O.R.S., Writing: A.U.Ö., O.R.S.

Conflict of Interest: No conflict of interest was declared by the authors.

Financial Disclosure: The authors declared that this study received no financial support.

\section{References}

1. Sipahi OR. Economics of antibiotic resistance. Expert Rev Anti Infect Ther. 2008;6:523-39.

2. TC Sağlık Bakanlığı, Özellikli Sağlık Hizmetleri Dairesi Başkanlığı. Last accessed date: 10.08.2018 Available from: http://hizmetstandartlari.saglik. gov.tr/dosya/1-97086/h/2014-ulusal-ozet-rapor-1.pdf

3. World Health Organization (WHO). The Global Patient Safety Challenge 2005-2006: Clean Care is Safer Care. IJID. Last accessed date: 10.08.2018. Available from: http://www.who.int/gpsc/en/

4. Semmelweis I. Etiology, concept, and prophylaxis of childbed fever (excerpts). In: Carter C (ed). $1^{\text {st }}$ ed. The University of Wisconsin Press, 1983.

5. Pittet D, Hugonnet $S$, Harbarth $S$, Mourouga $P$, Sauvan V, Touveneau $S$, Perneger TV. Effectiveness of a hospital-wide programme to improve compliance with hand hygiene. Infection Control Programme. Lancet. 2000;356:1307-12.

6. Erasmus V, Daha TJ, Brug $H$, Richardus JH, Behrendt MD, Vos MC, van Beeck EF. Systematic review of studies on compliance with hand hygiene guidelines in hospital care. Infect Control Hosp Epidemiol. 2010;31:283-94.
7. Luangasanatip $N$, Hongsuwan $M$, Limmathurotsakul $D$, Lubell $Y$, Lee AS, Harbarth S, Day NP, Graves N, Cooper BS. Comparative efficacy of interventions to promote hand hygiene in hospital: systematic review and network meta-analysis. BMJ. 2015;351:3728.

8. White $K M$, Jimmieson NL, Obst PL, Graves N, Barnett A, Cockshaw W, Gee P, Haneman L, Page K, Campbell M, Martin E, Paterson D. Using a theory of planned behaviour framework to explore hand hygiene beliefs at the ' 5 critical moments' among Australian hospital-based nurses. BMC Health Serv Res. 2015;15:59.

9. Dikiş $D$, Kepeli N, Deniz-Küçükler N, Ulusoy B, Korkmaz N, Akşit-Barık Ş, Sipahi OR, Arda B, Cilli F, Yesim-Metin D, Ulusoy S. 2014-2017 Yılları Arasında Sağlık Personelinin Mesleklere Göre El Hijyeni Uyum Oranları. Hastane İnfeksiyonları Dergisi. 2018;22:230.

10. Uyan A, Demiray K, Arı A, Alkan Çeviker $S$, Işık E, Senol $G$, Demiç $S$, Dogan $M$, Uğurlu $K$, Arslan $M$, Akdemir I, Koç $F$, Kürekçi $Y$, Çağlayan D, Sipahi $H$, Yamazhan T, Arda B, Ulusoy S, Resat Sipahi O. Are Soap, Paper Towel and Alcohol-based Disinfectants Easily Accessible in Intensive Care Units in Turkey?: Results of the Phokai Study. ECCMID. Vienna-Austria; 2017. p. 1512.

11. Karabey S, Çetinkaya ŞY, Alp E, Ergönül O, Esen Ş, Kaymakçı H. El Hijyeni Kılavuzu. Turkish Journal of Hospital Infections. 2008;12(Suppl 1):3-30. Last accessed date: 10.08.2018. Available from: http://www.hider.org.tr/global/ Dernek_Kilavuzlari/2008-12-Ek1-003-029.pdf

12. Pittet D. Improving compliance with hand hygiene in hospitals. Infect Control Hosp Epidemiol. 2000;21:381-6.

13. Uyan A, Durmus G, Sezak N, Pepe F, Kaygusuz T, Aksoy F, Erol S, Meriç-Koç M, Öncül A, Aktaş S, Caşkurlu H, Çelebi G, Evik G, Özger S, Harman R, Taşbakan $M$, Arda B, Ulusoy S, Sipahi OR. Are there enough nurses in Turkey? Results of the Multicenter Karia Study. ECCMID. Vienna-Austria; 2017. p. 0518.

14. Sunkesula VC, Meranda D, Kundrapu S, Zabarsky TF, McKee M, Macinga DR, Donskey CJ. Comparison of hand hygiene monitoring using the 5 Moments for Hand Hygiene method versus a wash in-wash out method. Am J Infect Control. 2015;43:16-9.

15. Huang GK, Stewardson AJ, Grayson ML. Back to basics: hand hygiene and isolation. Curr Opin Infect Dis. 2014;27:379-89.

16. Jarrin Tejada C, Bearman G. Hand hygiene compliance monitoring: the state of the art. Curr Infect Dis Rep. 2015;17:470.

17. Sanchez-Carrillo LA, Rodriguez-Lopez JM, Galarza-Delgado DA, Baena Trejo $\mathrm{L}$, Padilla-Orozco M, Mendoza-Flores L, Camacho-Ortiz A. Enhancement of hand hygiene compliance among health care workers from a hemodialysis unit using video-monitoring feedback. Am J Infect Control. 2016;44:86872.

18. Armellino $D$, Hussain $E$, Schilling $M E$, Senicola $W$, Eichorn $A$, Dlugacz $Y$, Farber BF. Using high-technology to enforce low-technology safety measures: the use of third-party remote video auditing and real-time feedback in healthcare. Clin Infect Dis. 2012;54:1-7.

19. Arda B, Şenol Ş, Taşbakan IM, Yamazhan T, Sipahi OR, Arsu G, Ulusoy S. Evaluation of adherence to hand cleaning rules in intensive care units of Ege University Medical Faculty. Turkish J Intensive Care Med. 2005;5:182-6.

20. Sönmezer $M C ̧$, Gülhan B, Otuzoğlu $M$, Yakut Hi, Tezer H. Evaluation of hand hygiene compliance in the pediatric intensive care unit. Türkiye Çocuk Hastalıkları Dergisi. 2014;8:75-8.

21. Balın ŞÖ, Şenol Aktaş A. Sağlık Personelinin El Hijyenine Uyumu, 6. EKMUD kongresi poster sunum, Mediterr J Infect Microb Antimicrob. 2016;5(Suppl 1):160-1. 